\title{
IN SILICO MOLECULAR DOCKING OF XANTHONE DERIVATIVES AS CYCLOOXYGENASE-2 INHIBITOR AGENTS
}

\author{
ISNATIN MILADIYAH ${ }^{1}$, JUMINA JUMINA², SOFIA MUBARIKA HARYANA ${ }^{3}$, MUSTOFA MUSTOFA ${ }^{4}$
}

1Pharmacology Department, Faculty of Medicine, Islamic University of Indonesia, Yogyakarta, ${ }^{2}$ Chemistry Department, Faculty of Mathematics and Natural Sciences, Gadjah Mada University, Yogyakarta, ${ }^{3}$ Histology and Cell Biology Department, Faculty of Medicine, Gadjah Mada University, Yogyakarta, ${ }^{4}$ Pharmacology and Therapeutic Department, Faculty of Medicine, Gadjah Mada University, Yogyakarta Email: isnatin@gmail.com

Received: 26 Sep 2016 Revised and Accepted: 17 Jan 2017

\begin{abstract}
Objective: To demonstrate the potential ofdifferent xanthone derivatives as cyclooxygenase-2 (COX-2) inhibitor agents and their selectivity against cycloooxygenase-1 (COX-1) and COX-2 using molecular simulation.

Methods: Nine novel xanthone derivatives (compounds A-I) were employed to dock against protein COX-2 (Protein Data Bank/PDB ID: 1CX2) and COX-1 (PDB ID: 3N8Z). Celecoxib, a selective COX-2 inhibitor, was chosen as a control compound. The free binding energy produced by the docking was scored using Protein-Ligand Ant System (PLANTS) and the hydrogen bonds (H-bonds) between ligands and enzymes were visualised using Pymol.

Results: Molecular docking studies revealed that celecoxib docked to the active site of COX-2 enzyme, but not to COX-1; where as xanthone derivatives docked to the active site of both COX-2 and COX-1. Free binding energy of xanthone derivatives ranged between-73, 57 to-79,18 and between-73,06 to-79,25 against COX-2 and COX-1, respectively, and-78,13 against celecoxib. H-bonds in the molecule of xanthone derivatives and COX-2 protein were found in amino acid residues $\operatorname{Arg}^{120}, \mathrm{Tyr}^{355}, \mathrm{Tyr}^{385}$, and $\mathrm{Ser}^{353}$. There was an insignificant difference between the free binding energy of xanthone derivatives against COX-2 and against COX-1, suggesting that their inhibition was non-selective.
\end{abstract}

Conclusion: In conclusion, in silico studies showed that xanthone derivatives could be effective as potential inhibitors against COX-2, although they are not selective.

Keywords: Xanthones, Molecular docking, Anticancer, COX-2, Selectivity

(C) 2016 The Authors. Published by Innovare Academic Sciences Pvt Ltd. This is an open access article under the CC BY license (http://creativecommons.org/licenses/by/4.0/) DOI: http://dx.doi.org/10.22159/ijpps.2017v9i3.15382

\section{INTRODUCTION}

The cyclooxygenase (COX) enzyme plays an important role in the production of prostaglandin from arachidonic acid, which is involved in various processes in the body, including inflammation, pain, and hyperpyrexia [1]. It is widely known that COX has two isoforms, namely COX-1 and COX-2. COX-1 is a constitutive part of the body thatmaintains the normal function of the gastrointestinal organs, the kidneys, and platelets, while COX-2 is an inducible enzyme that is primarily expressed by various pro-inflammatory cytokines, lipopolysaccharides, mitogens, and oncogens [2]. When COX-1 is inhibited, the inflammation process will decrease. Impairments in gastrointestinal mucous protection,as well asthe normal functions of the kidneys and platelets, along with other side effects,may occur [1].

Clinical data shows that, although COX-2 plays a role in the repairment of injury, excessive expression of this enzyme will promotevarious pathological processes, including carcinogenesis and cancer growth [3]. COX-2 enzymes are found to be highly expressed in a number of inflammatory processes and tumours, such as inflammatory bowel disease (IBD) and colon cancer, whereas it is minimal or undetected at the normal colon cell [4]. This iswhy research on new anti-inflammatory drugs has been focusing on the identification of compounds with selective activity against COX-2 in preventing the inflammation process.

A number of studies show that the inflammation process is involved in carcinogenesis. The immune system, cytokines, chemokines, and transcription factors are directly associated with malignancy, which together form an "orchestra" in the pathogenesis of cancer. Immune cells in the microenvironment with inflammation stimulate the production of cytokines and chemokines. These will activate transcription factors responsible for spreading the tumour (mainly nuclear factor kappa $\mathrm{B} / \mathrm{NFKB}$ and signal transducer and activator of transcription 3/STAT3) and stimulate other pro-inflammatory cytokines [5]. Therefore, inflammation can be considered as an initial form of tumour progression that may develop into a true cancer [6].

The use of aspirin and other non-steroidal anti-inflammatory drugs (NSAIDs) in chemoprevention of cancer has proven capable in reducing incidences of cancer and preventing mortality in some cancers, such as cancer ofthe colorectal [7], stomach [8], lung [9], breast [10], lymphatic tissue(Hodgkin lymphoma) [11], pancreas, oesophagus, kidney and bladder [12]. Aspirin and other NSAIDs act as antitumors by shifting the balance of Bax/Bcl-2 and activating a number of caspases [13], as antiplatelet drugs [14], by inhibiting the signalling process of NF- $\mathrm{KB}$ [16], as anti-angiogenesis drugs [17], and by inducing Rac1 gene involved in the apoptosis [18].

Selective COX-2 inhibitors were formerly developed as an antiinflammatory drug with fewer gastrointestinal side effects when compared to COX-1 [18]. In long-term use, some COX-2 inhibitors (rofecoxib and valdecoxib) increase the risk of heart attacks and strokes; thus, they were withdrawn from the market. Currently, celecoxib is the only COX-2 selective inhibitor available in the market [19]. There is a rising urge to develop a new selective COX-2 inhibitor with fewer side effects through a more effective and efficient drug discovery process.

A method to investigate a more effective and efficient new drug is using molecular docking. This is a part of molecular modelling that predicts interaction orientations (conformations) between two molecules precisely, as shown by the formation of a stable complex. The most preferred orientation (the best conformer) is indicated by the lowest binding energy and is associated with the strongest interaction. This method allows us to explore and investigate many drugs for the same receptor atthe same time. The drug with a better interaction between a ligand and a receptor will be chosen for use in laboratory experiments, and it saves resources and is less time-consuming [20]. 
This drug virtual-screening method is widely applied in structurebased drug design and can be performed for interaction modelling of ligands and proteins at an atomic level [21]. The chemical structure of certain drug receptor is downloaded from the Protein Data Bank (PDB) for investigation of their molecular docking capability at the active site, using computer algorithms and scoring functions [22]. This consists of basic processes, namely ligand conformation predictions at the receptor active site, placement and orientation of the conformations, and their binding affinity [21]. Interactions between ligands and receptors, as indicated by their scoring function, are ranked; ligands with the lowest score will be investigated further. This step will make molecular docking an important part of more effective and efficient drug discovery, because it saves time and money [22].

Xanthone derivative is one compound known for analgesic and antiinflammation activity. Natural xanthones can be isolated from a variety of plants, including Garcinia mangostana [23], Hypericum perforatum [24], Calophylum inophylum [25], Gamboge hanburyi [26], and Artocarpus optusus [27]. Xanthones have an anti-inflammatory effect by inhibiting COX-2 and prostaglandin synthesis at glioma cell in rats [28], without affecting the constitutive COX-1 [29].

The docking of natural xanthones from Garcinia mangostana [30] and propoxy-and pentyloxy-substituted synthetic xanthones [31] are studied against COX-2 enzymes. The result showed that xanthone ligands were docked to the receptor and formed stable complexes through several interactions. The bond between drugs and receptors are categorised as weak and are formed through noncovalent interactions, such as van der Waals, hydrophobic, and hydrogen. This means the effects are reversible. A hydrogen bond (H-bond) has the strongest affinity with the distance below $3.2 \AA$ [32] and is the main interaction contributing to binding energy.

A number of xanthone derivatives were newly synthesised by Yuanita (Organic Chemistry of Mathematics and Natural Sciences Faculty, Gadjah Mada University). These xanthones have not yet been studied for their COX-2 inhibitory activity. This study aims to investigate the molecular docking of hydroxy-and polyhydroxysubstituted xanthones against COX-1 and COX-2 receptors. This is to predict their inhibitory activities and the possibility of their selectivity.

\section{MATERIALS AND METHODS}

\section{Material preparation}

Three-dimension (3D) structures of enzymes were downloaded from theProtein Data Bank database (www. rcsb. org) with PDB ID: 3N8Z for COX-1 and1CX2for COX-2.3N8Zstructure has a native ligand FLP (flerbuprofen), and1CX2is a complex of COX-2 enzymes with native ligand SC-558 -a selective COX-2 inhibitor. A series of hydroxy-and polyhydroxy-substituted xanthones derivatives (compound A-I) were used as experimental ligands (fig. 1).

The 3D structures of COX-1 and COX-2 that were downloaded were prepared with YASARA (http://www.yasara.org) in the standard setting. Only A-chain of the protein extracted from the PDB file and hydrogen atoms were included in the preparation process. The results were saved in the. mol 2 format and would be a virtual target for docking simulation. The downloaded native ligands (FLP andSC558) were prepared with Marvin sketch by configuring them into two dimension (2D) formats. Theywere protonated at pKa 7.4, and ligand conformations were performed. The ten conformers form FLP and SC-558 ligands were saved in the. mol2 format for the next docking process.

The 2D structure of nineexperimental ligands were constructed with Marvin sketch 5.2.5.1 (http://www.chemaxon.com) [33]. The preparation for these ligands was performed inthe same way as the native ligands and the conformers saved in the. mol 2 format for the docking process. Celecoxib (IUPAC name 4-[5-(4-methylphenyl)-3(trifluoromethyl) pyrazol-1-yl] benzen and Pubchem CID 2662) were used as a control for COX-2 selective inhibitors, and the ligand preparation was done in the same way as the others.
A

C<smiles>O=c1c2ccccc2oc2cc(O)ccc12</smiles>

E<smiles>O=c1c2ccccc2oc2c(O)c(O)ccc12</smiles><smiles>O=c1c2ccc(O)cc2oc2cc(O)cc(O)c12</smiles>

G<smiles>O=c1c2ccccc2oc2ccc(Cl)cc12</smiles>

I
B<smiles>O=c1c2ccccc2oc2cc(O)cc(O)c12</smiles>

D<smiles>O=c1c2ccc(O)cc2oc2cc(O)ccc12</smiles>

F<smiles>O=c1c2ccc(O)cc2oc2c(O)c(O)ccc12</smiles>

H<smiles>O=c1c2ccc(Cl)cc2oc2ccc(O)cc12</smiles>

\section{Docking molecular process}

Docking program simulations used PLANTS/Protein-Ligand Ant System [34], and the docking parameter (root median square deviation/RMSD and free binding energy) were measured with YASARA (http://www.yasara.org). Root median square deviation for SC-558 was overlapping conformation of the copy ligand SC-558 after redocking against COX-2 active site, when compared to the ligand structure from measurements from the x-ray crystal. Also, RMSD for FLP was overlapping ligand FLP against the active site of COX-1. The smaller the RMSD value, the smaller thecoordinate difference between two ligands, and the ligand structures that overlapped were more similar [35]. A docking program is valid and suitable for reproducing if the RMSD $<2 \AA$ [36]. In the PLANTS program, the binding site definition file is set to $5 \AA$ from the coordinate location where SC-558 was bound to COX-2 and IBP was bound to COX-1. The position with the best 
score (the most electronegative) was selected as the best predictive binding position [37].

The Pymol program (www.pymol.org) was used to see the H-bonds between ligand and the receptor [38]. Amino acid residues that interacted with the redocking compound were compared to those that interacted with the crystal molecule.

\section{RESULTS AND DISCUSSION}

COX- 1 and COX- 2 active sites have a similar structure, with the major differences being isoleusin substitution at amino acid residues 434 and 523 COX-1 ( $\mathrm{Ile}^{434}$ and Ile ${ }^{523}$ ) to valin at COX2 (Val ${ }^{434}$ and Val ${ }^{523}$ ) at the side pocket(2). The smaller valin residue at COX-2 forms a hydrophobic area and secondary pocket, due to pharmacophore $\mathrm{SO}_{2} \mathrm{Me}$ and $\mathrm{SO}_{2} \mathrm{NH}_{2}$ [39]. This secondary pocket in the COX-2 receptor is absent in COX-1, and become a target for the COX-2 selective inhibitor [40]. Another difference is that, in the side pocket, amino acid histidin (His ${ }^{513}$ ) for COX-1 is replaced by arginin (Arg ${ }^{513}$ ) in COX-2 and it allows interaction between the COX-2 receptor with polar compounds [41]. These basic differences at the COX-2 active sites are underlying selective mechanisms of COX-2 over the COX-1 receptor.
In this study, the inhibition of xanthone compounds against COX-2 and COX-1 enzymes was conducted in silico using a docking program named PLANTS. The PLANTS program has the ability to make a good prediction performance, and it can be performed in a short time [34]. The molecular docking process aims to predict the receptor ligandbinding mode, indicated by docking accuracy. Docking accuracy was considered successful if the RMSD value is less than $2 \AA$, and the process of docking the experimental compounds can be done.

\section{Docking method validation}

The redocking process of native ligands SC-558 and FLP was performed in a way as mentioned in the method. YASARA showed that the ligand copy almost coincides with COX-2 binding site at $1.3855 \AA$ RMSD value, while COX- 1 was at $0.33874 \AA$ (both less than $2 \AA$ ); these met the validity criteria of docking. Comparison between the ligand conformation SC-558 and FLP from the x-ray crystal structure with redocking calculation results can be seen in fig. 2. The free binding energy between the copy ligand with COX-1 and COX-2 active site were-96.48 and-79.22, respectively. H-bonds or polar contacts of copy ligand with COX-1 enzyme were at amino acid residue Leu ${ }^{352}$, whereas those at COX-2 were in the positions of Ser 353 and Arg ${ }^{513}$ (fig. 3).

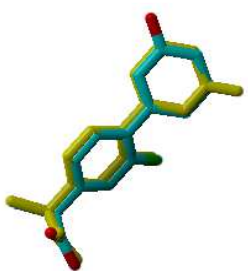

(a) $3 N 8 Z$ (RMSD = 0,3874 Å)

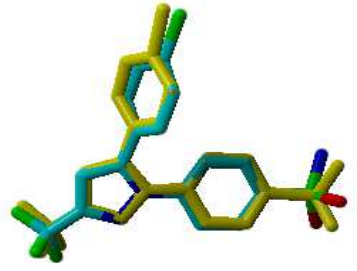

(b) 1 CX2 (RMSD = 1,3855 ̊̊)

Fig. 2: Comparison of conformation between the native ligand of the X-ray crystal structure (yellow) to the docking result (blue) and its RMSD values (<2 Å) (a) COX-1, (b) COX-2

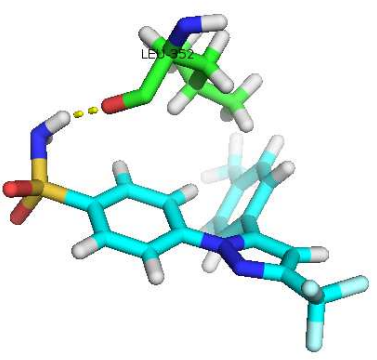

(a) COX-1

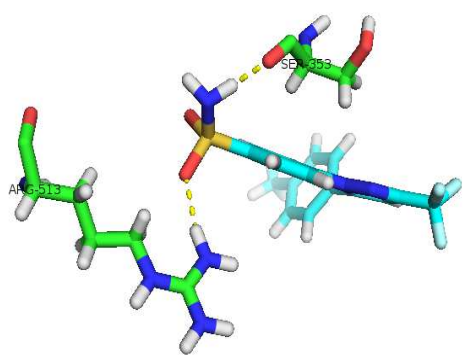

(b) $\operatorname{coX}-2$

Fig. 3: H-bond positions among native ligands with amino acid residues of the COX-1 receptor (Leu ${ }^{352}$ ) (a) and with the COX-2 (Ser ${ }^{353}$ and Arg ${ }^{513}$ ) (b). Yellow dashed lines indicate the $\mathrm{H}$-bonds between the ligands and protein

\section{Docking molecular of celecoxib against COX-1 and COX-2 enzymes}

The best conformation celecoxib docking with COX-1 and COX-2 enzymes is illustrated in fig. 4. It appears that the native ligand

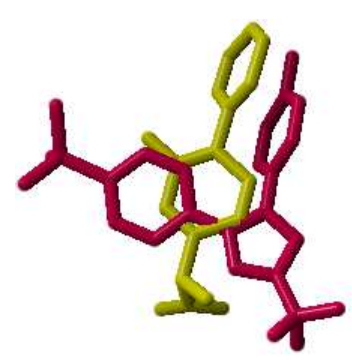

(a) $3 N 8 Z$ (yellow) and celecoxib (red) coincide; for the COX-2 enzyme, this overlap is very similar to the results of redocking native ligand (fig. 1b), while crossing each other for the COX-1.

Fig. 4: Results of the celecoxib docking with native ligand of COX-1 (a) and COX-2 (b), performed with YASARA. Native ligand is yellow,

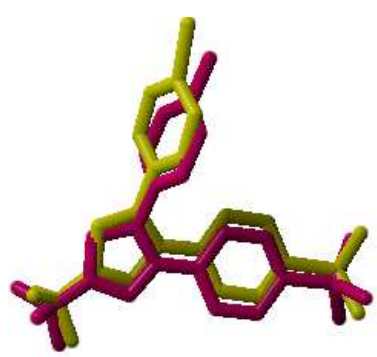

(b) ICX2 whereas celecoxib is red 
The docking results of celecoxib and xanthone compounds against the enzyme COX-1 are shown in table 1, whereas that against COX-2 is listed in table 2. It appears that celecoxib, a COX-2 selective inhibitor, has free binding energy-78.13 (close to free binding energy of native ligand), while the enzyme COX-1 is much higher, at-34.01. Results of the celecoxib docking with native ligand 1CX2 and 3N8Z (fig. 4) may rationalise the extreme difference of free binding energy between the celecoxib with COX-1 and COX-2 enzymes. In this study, the more similar the docking overlap between the drugs with itsreceptor, the lower the energy that is generated; it also forms a more stable complex.

Table 1: Result of xanthones docking against the enzyme COX-1 (3N8Z), amino acid residues involved, and the number of hydrogen bonds

\begin{tabular}{|c|c|c|c|c|}
\hline \multirow[t]{2}{*}{ Compound } & \multirow[t]{2}{*}{ Free energy } & \multicolumn{3}{|l|}{ H-bonds } \\
\hline & & Atom component & Amino acid residues & $\mathbf{n}$ \\
\hline Celecoxib & $-34,01$ & $\mathrm{H}$ of $\mathrm{NH}$ & $\mathrm{O}$ atom $(\mathrm{C}=0)$ of $\mathrm{Leu}^{352}$ & 1 \\
\hline \multirow[t]{2}{*}{ A } & $-77,24$ & $\mathrm{H}$ of $\mathrm{OH}(\mathrm{C}-3)$ & $\mathrm{O}$ atom $(\mathrm{C}=0)$ of $\mathrm{Met}^{522}$ & 2 \\
\hline & & $\mathrm{O}$ of $\mathrm{C}=\mathrm{O}$ & $\mathrm{H}$ atom $(\mathrm{OH})$ of Ser 530 & \\
\hline \multirow[t]{2}{*}{ B } & $-74,90$ & $\mathrm{H}$ of $\mathrm{OH}(\mathrm{C}-3)$ & $\mathrm{O}$ atom $(\mathrm{C}=0)$ of $\mathrm{Met}^{522}$ & 2 \\
\hline & & $\mathrm{O}$ of $\mathrm{C}=\mathrm{O}$ & $\mathrm{H}$ atom $(\mathrm{OH})$ of $\mathrm{Ser}^{530}$ & \\
\hline \multirow[t]{3}{*}{$\mathrm{C}$} & $-76,30$ & $\mathrm{H}$ of $\mathrm{OH}(\mathrm{C}-3)$ & $\mathrm{O}$ atom $(\mathrm{C}=0)$ of $\mathrm{Met}^{522}$ & 3 \\
\hline & & $\mathrm{H}$ of $\mathrm{OH}(\mathrm{C}-4)$ & $\mathrm{O}$ atom $(\mathrm{C}=0)$ of $\mathrm{Met}^{522}$ & \\
\hline & & $\mathrm{O}$ of $\mathrm{C}=\mathrm{O}$ & $\mathrm{O}$ atom $(\mathrm{OH})$ of $\mathrm{Ser}^{530}$ & \\
\hline \multirow[t]{4}{*}{ D } & $-74,94$ & $\mathrm{O}$ of $\mathrm{OH}(\mathrm{C}-6)$ & $\mathrm{H}$ atom $(\mathrm{NH})$ of $\operatorname{Arg}^{120}$ & 4 \\
\hline & & $\mathrm{O}$ of $\mathrm{OH}(\mathrm{C}-6)$ & $\mathrm{H}$ atom $(\mathrm{NH})$ of $\operatorname{Arg}^{120}$ & \\
\hline & & $\mathrm{H}$ of $\mathrm{OH}(\mathrm{C}-3)$ & $\mathrm{O}$ atom $(\mathrm{C}=0)$ of $\mathrm{Met}^{522}$ & \\
\hline & & $\mathrm{O}$ of $\mathrm{C}=\mathrm{O}$ & $\mathrm{H}$ atom $(\mathrm{OH})$ of $\mathrm{Ser}^{530}$ & \\
\hline \multirow[t]{5}{*}{$\mathrm{E}$} & $-77,57$ & $\mathrm{O}$ of $\mathrm{OH}(\mathrm{C}-6)$ & $\mathrm{H}$ atom $(\mathrm{NH})$ of $\operatorname{Arg}^{120}$ & 5 \\
\hline & & $\mathrm{O}$ of $\mathrm{OH}(\mathrm{C}-6)$ & $\mathrm{H}$ atom $(\mathrm{NH})$ of $\operatorname{Arg}^{120}$ & \\
\hline & & $\mathrm{O}$ of $\mathrm{OH}(\mathrm{C}-6)$ & $\mathrm{O}$ atom $(\mathrm{OH})$ of $\mathrm{Tyr}^{355}$ & \\
\hline & & $\mathrm{H}$ of $\mathrm{OH}(\mathrm{C}-3)$ & $\mathrm{O}$ atom $(\mathrm{C}=0)$ of $\mathrm{Met}^{522}$ & \\
\hline & & $\mathrm{O}$ of $\mathrm{C}=\mathrm{O}$ & $\mathrm{H}$ atom $(\mathrm{OH})$ of $\mathrm{Ser}^{530}$ & \\
\hline \multirow[t]{4}{*}{$\mathrm{F}$} & $-73,96$ & $\mathrm{O}$ of $\mathrm{OH}(\mathrm{C}-6)$ & $\mathrm{H}$ atom $(\mathrm{NH})$ of $\operatorname{Arg}^{120}$ & 4 \\
\hline & & $\mathrm{O}$ of $\mathrm{OH}(\mathrm{C}-6)$ & $\mathrm{H}$ atom $(\mathrm{NH})$ of $\operatorname{Arg}^{120}$ & \\
\hline & & $\mathrm{H}$ of $\mathrm{OH}(\mathrm{C}-4)$ & $\mathrm{O}$ atom $(\mathrm{C}=0)$ of $\mathrm{Met}^{522}$ & \\
\hline & & $\mathrm{O}$ of $\mathrm{C}=\mathrm{O}$ & $\mathrm{H}$ atom $(\mathrm{OH})$ of $\mathrm{Ser}^{530}$ & \\
\hline G & $-77,53$ & $\mathrm{O}$ of $\mathrm{C}=\mathrm{O}$ & $\mathrm{H}$ atom $(\mathrm{OH})$ of $\operatorname{Ser}^{530}$ & 1 \\
\hline \multirow[t]{2}{*}{$\mathrm{H}$} & $-79,25$ & $\mathrm{H}$ of $\mathrm{OH}(\mathrm{C}-6)$ & $\mathrm{O}$ atom $(\mathrm{C}=0)$ of $\mathrm{Met}^{522}$ & 2 \\
\hline & & $\mathrm{O}$ of $\mathrm{C}=\mathrm{O}$ & $\mathrm{H}$ atom $(\mathrm{OH})$ of Ser 530 & \\
\hline \multirow[t]{3}{*}{ I } & $-76,17$ & $\mathrm{O}$ of $\mathrm{OH}(\mathrm{C}-5)$ & $\mathrm{O}$ atom $(\mathrm{C}=0)$ of $\mathrm{Met}^{522}$ & 3 \\
\hline & & $\mathrm{O}$ of $\mathrm{OH}(\mathrm{C}-6)$ & $\mathrm{O}$ atom $(\mathrm{C}=0)$ of $\mathrm{Met}^{522}$ & \\
\hline & & $\mathrm{O}$ of $\mathrm{C}=\mathrm{O}$ & $\mathrm{H}$ atom $(\mathrm{OH})$ of $\mathrm{Ser}^{530}$ & \\
\hline
\end{tabular}

Table 2: Results of xanthones docking towards enzyme COX-2 (1CX2), amino acid residues involved, and the number of hydrogen bonds

\begin{tabular}{|c|c|c|c|c|}
\hline \multirow[t]{2}{*}{ Compound } & \multirow[t]{2}{*}{ Free energy } & \multicolumn{3}{|l|}{ H-bonds } \\
\hline & & Atom component & Amino acid residues & $\mathbf{n}$ \\
\hline \multirow[t]{2}{*}{ Celecoxib } & $-78,13$ & 0 of $S=0$ & $\mathrm{O}$ atom $(\mathrm{C}=0)$ of $\mathrm{Ser}^{353}$ & 2 \\
\hline & & $\mathrm{H}$ of $\mathrm{NH}$ & $\mathrm{H}$ atom $(\mathrm{NH})$ of $\mathrm{Arg}^{513}$ & \\
\hline A & $-79,18$ & None & & 0 \\
\hline B & $-77,23$ & none & & 0 \\
\hline \multirow[t]{3}{*}{$\mathrm{C}$} & $-77,36$ & $\mathrm{O}$ of $\mathrm{OH}(\mathrm{C}-3)$ & $\mathrm{H}$ atom $(\mathrm{NH})$ of $\operatorname{Arg} 120$ & 3 \\
\hline & & $\mathrm{H}$ of $\mathrm{OH}(\mathrm{C}-3)$ & $\mathrm{O}$ atom $(\mathrm{OH})$ of $\mathrm{Tyr}^{355}$ & \\
\hline & & $\mathrm{H}$ of $\mathrm{OH}(\mathrm{C}-4)$ & $\mathrm{O}$ atom $(\mathrm{OH})$ of $\mathrm{Tyr}^{355}$ & \\
\hline \multirow[t]{2}{*}{ D } & $-75,64$ & $\mathrm{O}$ of $\mathrm{OH}(\mathrm{C}-6)$ & $\mathrm{O}$ atom $(\mathrm{NH})$ of His ${ }^{90}$ & 2 \\
\hline & & $\mathrm{O}$ of $\mathrm{OH}(\mathrm{C}-6)$ & $\mathrm{O}$ atom $(\mathrm{C}=0)$ of $\mathrm{Ser}^{353}$ & \\
\hline \multirow[t]{3}{*}{$\mathrm{E}$} & $-77,21$ & $\mathrm{O}$ of $\mathrm{OH}(\mathrm{C}-6)$ & $\mathrm{H}$ atom $(\mathrm{NH})$ of $\operatorname{Arg} 120$ & 3 \\
\hline & & $\mathrm{O}$ of $\mathrm{OH}(\mathrm{C}-6)$ & $\mathrm{O}$ atom $(\mathrm{OH})$ of $\mathrm{Tyr}^{355}$ & \\
\hline & & $\mathrm{H}$ of $\mathrm{OH}(\mathrm{C}-1)$ & $\mathrm{O}$ atom $(\mathrm{OH})$ of $\mathrm{Tyr}^{385}$ & \\
\hline \multirow[t]{3}{*}{$\mathrm{F}$} & $-77,03$ & $\mathrm{O}$ of $\mathrm{OH}(\mathrm{C}-3)$ & $\mathrm{H}$ atom $(\mathrm{NH})$ of $\operatorname{Arg}^{120}$ & 3 \\
\hline & & $\mathrm{H}$ of $\mathrm{OH}(\mathrm{C}-3)$ & 0 atom $(\mathrm{OH})$ of $\mathrm{Tyr}^{355}$ & \\
\hline & & $\mathrm{H}$ of $\mathrm{OH}(\mathrm{C}-4)$ & $\mathrm{O}$ atom $(\mathrm{OH})$ of Tyr 355 & \\
\hline G & $-77,93$ & none & & 0 \\
\hline \multirow[t]{2}{*}{$\mathrm{H}$} & $-73,57$ & $\mathrm{O}$ of $\mathrm{OH}(\mathrm{C}-6)$ & $\mathrm{H}$ atom $(\mathrm{NH})$ of $\operatorname{Arg} 120$ & 2 \\
\hline & & $\mathrm{H}$ of $\mathrm{OH}(\mathrm{C}-6)$ & $\mathrm{H}$ atom $(\mathrm{OH})$ of $\mathrm{Tyr}^{355}$ & \\
\hline \multirow[t]{2}{*}{ I } & $-76,67$ & $\mathrm{O}$ of $\mathrm{OH}(\mathrm{C}-5)$ & $\mathrm{H}$ atom $(\mathrm{NH})$ of $\operatorname{Arg}^{120}$ & 2 \\
\hline & & $\mathrm{O}$ of $\mathrm{OH}(\mathrm{C}-6)$ & $\mathrm{H}$ atom $(\mathrm{NH})$ of $\operatorname{Arg}^{120}$ & \\
\hline
\end{tabular}

The free binding energy between celecoxib with COX-1 is very high $(-34.01)$ while the COX-2 is quite low $(-78.13)$ and is close to the energy of the native ligand. This indicates the COX-2 selectivity of celecoxib. Celecoxib docked to COX-2 enzyme with minimal free binding energy and $\mathrm{H}$-bond is similar to then ative ligand, at Ser ${ }^{353}$ and Arg513. H-bonds between ligand and enzyme can predict the strength and the catalytic activity of that complex [42].
It appears that free binding energy throughout xanthones derivatives of COX-2 enzyme is higher than celecoxib (except for compound A) and it is assumed that interactions of xanthone derivatives with the active site of COX-2 are weaker than celecoxib. The interaction energy against COX-1 is lower than celecoxib, which indicates that xanthones are also able to bind strongly to receptor enzyme COX-1; thus they are not selective for COX-2. The number of H-bonds between xanthones and COX enzymes is comparable for both COX-1 and COX-2 (table 1), 
while the residue of primary amino acids are $\operatorname{Arg}^{12^{\circ}}, \operatorname{Ser}^{53^{\circ}}$ and $\operatorname{Met}^{522}$ in COX-1, whereas in COX-2 they are $\operatorname{Arg}^{12^{\circ}}, \mathrm{Tyr}^{355}, \mathrm{Tyr}^{385}$, and $\operatorname{Ser}^{353}$ (table 2). These polar contacts of xanthones with both COX-1 and COX-2 enzymes differ greatly with celecoxib.

Fig. 5 shows the orientation of the ligand (celecoxib and compound F) against COX-1 enzyme, while against COX-2 is shown in fig. 6. It appears that celecoxib and compound $\mathrm{F}$ are capable of occupying the active site of COX-2 and COX-1 enzymes, though the H-bonds positions were at different amino acid residues. Celecoxib and compound $\mathrm{F}$ are located in an area bounded by several amino acid residues; among them are $\operatorname{Trp}^{385}, \operatorname{Trp}^{387}, \mathrm{Phe}^{518}, \mathrm{Val}^{523}$ (in COX-1 is Ile ${ }^{523}$ ), His[90], $\mathrm{Leu}^{352}, \mathrm{Leu}^{531}, \mathrm{Ala}^{527}, \mathrm{Val}^{349}, \mathrm{Gly}^{526}$, and $\mathrm{Ser}^{53^{\circ}}$ (some other amino acids did not appear in the picture). This docking data isin line with a number studies of synthetic compounds, in which the interaction involved amino acid residues $\mathrm{His}^{90}, \mathrm{Arg}^{120}, \mathrm{Gln}^{192}, \mathrm{Val}^{349}, \mathrm{Leu}^{352}, \mathrm{Ser}^{353}$,

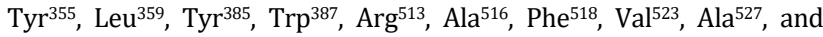
$\mathrm{Leu}^{352}$. All the residues involved in protein-ligand interactiondetermine the inhibition activity of COX enzymes [2]. These amino acid similarities indicate that xanthones are able to occupy the active site of the COX-2 enzyme, and are believed to engage ininhibitory activity against the COX-2 enzyme.

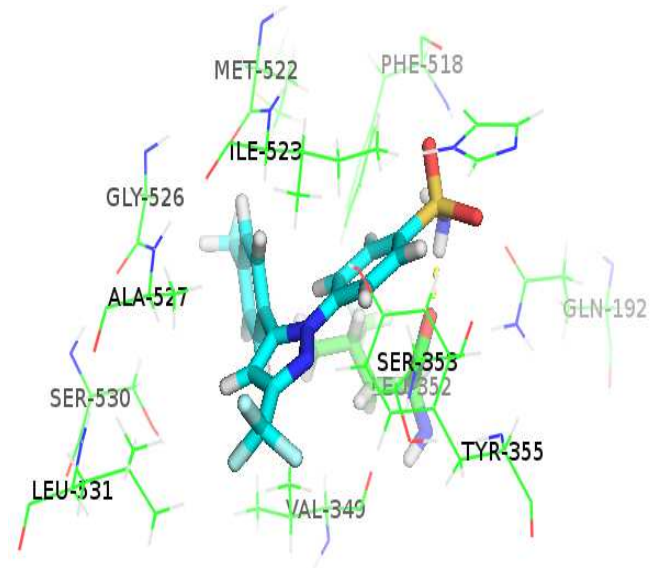

(a)

Celecoxib

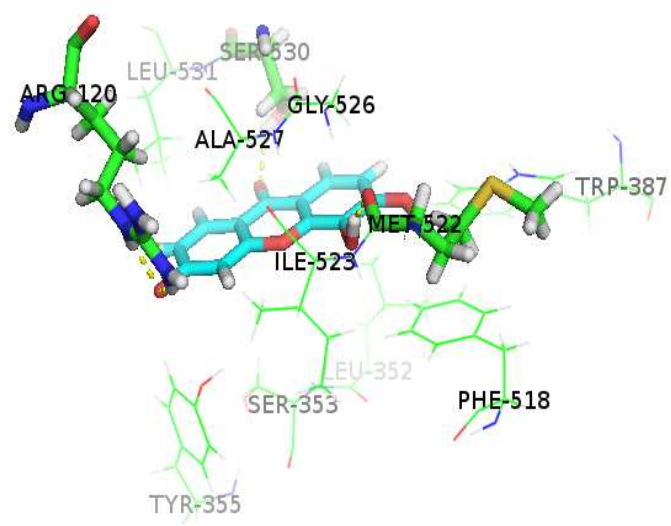

(b) Compound F

Fig. 5: Orientation of celecoxib (a) and compound $F(b)$ at the active site of the COX-1 enzyme

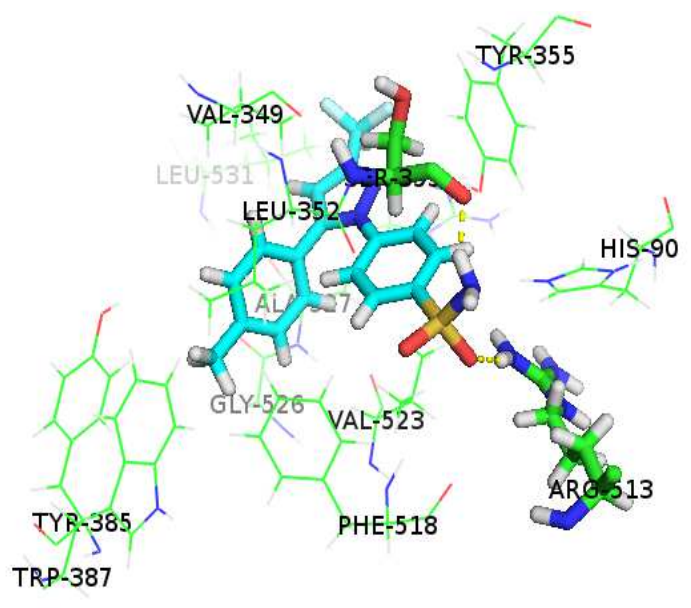

(a)
Celecoxib

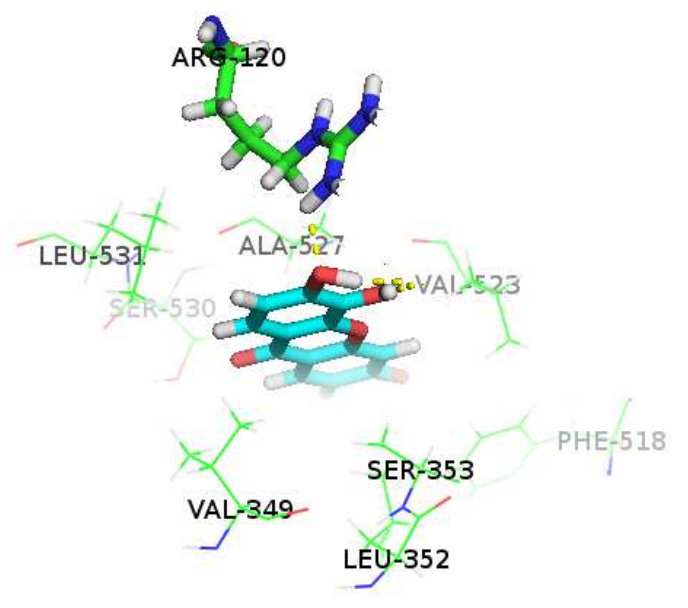

(b)

Compound F

Fig. 6: Orientation of celecoxib (a) and compound F (b) at the active site of the COX-2 enzyme

The active site of the COX-2 enzyme has three important regions. First there is the hydrophobic pocket, which is lined with amino acid residues $\mathrm{Tyr}^{385}, \mathrm{Trp}^{387}$, $\mathrm{Phe}^{518}, \mathrm{Ala}^{201}, \mathrm{Tyr}^{248}$, and $\mathrm{Leu}^{352}$. The second region is located at the gates of the active site and contains hydrophilic amino acid residues $\operatorname{Arg}^{120}$, $\mathrm{Glu}^{524}$, and $\mathrm{Tyr}^{355}$; while the third is a side pocket with amino acid residues His ${ }^{90}, \operatorname{Arg}^{513}$, and $\operatorname{Val}^{523}$ [19]. Some amino acid residues $\left(\operatorname{Arg}{ }^{12}{ }^{\circ}, \operatorname{Tyr}^{355}, \operatorname{His}^{90}, \operatorname{Arg}^{513}\right.$, $\mathrm{Val}^{523}$, Ser ${ }^{353}$, and $\mathrm{Glu}^{124}$ are believed to play a major role as a gateway entry of the ligand into the active site of the COX-enzyme, as shown in the analysis of the crystal structure of several inhibitors of COX-2 selective [43]. Several previous studies have shown that residue $\mathrm{Arg}^{513}$ is involved in the interaction of $\mathrm{H}$-bond formation in several compounds COX-2 selective inhibitors [44-45]. The low energy interactions and the similarity of amino acid residues with the native ligand in COX-2 docking process showed its activity as a selective inhibitor of COX-2.

The interaction energy of xanthone compounds against the COX-2 enzyme varies between-73.57 to-79.18, with $\mathrm{H}$-bonds found at amino acid residues $\operatorname{Arg}^{12}{ }^{\circ}, \mathrm{Tyr}^{355}, \mathrm{Tyr}^{385}$, and $\mathrm{Ser}^{353}$. These energies are slightly different to celecoxib (-78.13). H-bonds between the ligand and protein at amino acid residues $\operatorname{Arg}^{120}$ and $\mathrm{Tyr}^{355}$ are associated with formation of a stable complex in the COX-2 pockets in the celecoxib, indomethacin, and diclofenac; they are selective inhibitors of COX-2 [43]. The presence of H-bonds to the residue $\operatorname{Arg}^{12}{ }^{\circ}, \operatorname{Tyr}^{355}, \operatorname{Tyr}^{385}$, and $\operatorname{Ser}^{53^{\circ}}$ are also associated with better COX-2 inhibitory activity [46].

In general, it appears that the overall xanthone derivatives show good docking capability of the protein COX-2; however they have 
planar-shaped structures. This is slightly different from previous studies, in which it is mentioned that, if a compound is planar, it will have a little activity against receptor interactions COX-2 [47]. The free binding energy of xanthones against the enzyme COX-1 and COX-2 show small differences with-73.06 and-79.25 for COX-1, and73.57 and-79.18 for COX-2. The slight difference of interaction energy and the number of $\mathrm{H}$-bonds between xanthones and both COX ssuggest that the compounds have an equal COX-1 and COX-2 inhibitory activity or equipotency. For compounds with equipotency, the greater the molecule size, the more selective the inhibitory activity against COX-2. This is due to the increasing volume of the active site [48]. But of course this needs further investigation involving laboratory experimental studies.

\section{CONCLUSION}

Xanthone derivative compounds exhibit good inhibitory activity against the COX-2 enzyme. This is because they are able to occupy the COX- 2 receptor in the active site comparable with celecoxib, but not at the same active sites. The free binding energy between xanthones with COX-2 and COX-1 enzymes is slightly different, so inhibition of COX-2 by xanthones are non-selective.

\section{ACKNOWLEDGEMENT}

We would like to thank Emmy Yuanita (Departement of Organic Chemistry, Faculty of Mathematics and Natural Sciences, Gadjah Mada University) for permission to use the xanthone derivatives in this study.

\section{CONFLICT OF INTERESTS}

Allthe authors declared that there is no conflict of interest

\section{REFERENCES}

1. Jarapula R, Gangarapu K, Manda S, Rekulapally S. Seynthesis, in vivo anti-inflammatory activity, and molecular docking studies of new isatin derivatives. Int J Med Chem 2016. http://dx.doi.org/10.1155/2016/2181027.

2. Kurumbail RG, Stevens AM, Gierse JK, McDonald JJ, Stegeman RA, Pak JY, et al. Structural basis for selective inhibition of cyclooxigenase- 2 by anti-inflammatory agents. Nature 1996;384:400-2.

3. Barone M, Pannuzzo G, Santagati A, Catalfo A, Guidi G De, Cardile V. Molecular docking and fluorescence characterization of benzothieno[3,2-d]pyrimidin-4-one sulphonamide thioderivatives, a novel class of selective cyclooxygenase-2 Inhibitors. Molecules 2014;19:6106-22.

4. Moossavi S, Bishehsari F. Inflammation in sporadic colorectal cancer. Arch Iranian Med 2012;15:166-70.

5. Deng $\mathrm{S}, \mathrm{Hu} \mathrm{B}$, Shen $\mathrm{K}, \mathrm{Xu}$ L. Inflammation, macrophage in cancer progression and chinese herbal treatment. J Basic Clin Pharm 2012;3:269-72.

6. Hanahan D, Weinberg RA. Review hallmarks of cancer: the next generation. Cell 2011;144:646-74.

7. Rothwell PM, Fowkes FGR, Belch JF, Ogawa H, Warlow CP, Meade TW. Effect of daily aspirin on long-term risk of death due to cancer: analysis of individual patient data from randomised trials. Lancet 2011;377:31-41.

8. Wang WH, Huang JQ. Non-steroidal anti-inflammatory drug use and the risk of gastric cancer: a systematic review and metaanalysis. J Nat Cancer Inst 2003;95:1784-91.

9. McCormack V, Hung RJ, Brenner DR, Bickeboller $\mathrm{H}$, Rosenberger A, Muscat JE, et al. Aspirin and NSAID use and lung cancer risk: a pooled analysis in the international lung cancer consortium (ILCCO). Cancer Causes Control 2011;22:1709-20.

10. Holmes MD, Chen WY, Li L, Hertzmark E, Spiegelman D, Hankinson SE. Aspirin intake and survival after breast cancer. J Clin Oncol 2010;28:1467-72.

11. Chang ET, Zheng T, Weir EG, Borowitz M, Mann RB, Spiegelman $\mathrm{D}$, et al. Aspirin and the risk of hodgkin's lymphoma in a population-based case-control study. J Nat Cancer Inst 2004;96:305-15.

12. Bosetti C, Gallus S, Vecchia C La. Aspirin and cancer risk: a summary review to 2007. Cancer Prevention II Recent Res Cancer Res 2009;181:31-51.
13. Gu Q, De Wang J, Xia HHX, Lin MCM, He H, Zou B, et al. Activation of the caspase-8/Bid and Bax pathways in aspirin-induced apoptosis in gastric cancer. Carcinogenesis 2005;26:541-6.

14. Bambace NM, Holmes CE. The platelet contribution to cancer progression. J Thromb Haemostasis 2011;9:237-49.

15. Chattopadhyay M, Kodela R, Nath N, Barsegian A. Hydrogen sulfide-releasing aspirin suppresses NF-k B signaling in estrogen receptor negative breast cancer cells in vitro and in vivo. Biochem Pharmacol 2012;83:723-32.

16. Tsujii M, Kawano S, Tsuji S, Sawaoka H, Hori M, Dubois RN. Cyclooxygenases regulates angiogenisis induced by colon cancer cells. Cell 1998;93:705-16.

17. Hardwick JCH, van Santen M, van den Brink GR, van Deventer SJH, Peppelenbosch MP. DNA array analysis of the effects of aspirin on colon cancer cells: involvement of Rac1. Carcinogenesis 2004;25:1293-8.

18. Silverstein FE, Faich G, Goldstein JL, Simon LS, Pincus T, Whelton A, et al. Gastrointestinal toxicity with celecoxib vs nonsteroidal anti-inflammatory drugs for osteoarthritis and rheumatoid arthritis. JAMA 2000;284:1247-55.

19. Krishna PS, Vani K, Prasad MR, Samatha B, Bindu NSVSSSLH, Charya MAS, et al. In silico molecular docking analysis of prodigiosin and cycloprodigiosin as COX-2 inhibitors. Springerplus 2013;2:172-7.

20. Mukesh B, Rakesh K. Molecular docking: a review. Int J Res Ayurveda Pharm 2011;2:1746-51.

21. Meng XY, Zhang HX, Mezei M, Cui M. Molecular docking: a powerful approach for structure-basde drug discovery NIH public access. Curr Comput Aided Drug Des 2011;7:146-57.

22. Lavecchia A, Giovanni CD. Virtual screening strategies in drug discovery: a critical review. Curr Med Chem 2013;20:2839-60.

23. Chen LG, Yang LL, Wang CC. Anti-inflammatory activity of mangostins from Garcinia mangostana. Food Chem Toxicol 2008;46:688-93.

24. Crockett SL, Poller B, Tabanca N, Pferschy-Wenzig EM, Kunert 0 , Wedge DE, et al. Bioactive xanthones from the roots of hypericum perforatum (common St John's wort). J Sci Food Agric 2011;91:428-34.

25. Chan KM, Hamzah R, Rahaman AA, Jong VYM, Khong HY, Rajab $\mathrm{NF}$, et al. The pyranoxanthone inophyllin a induces oxidative stress mediated-apoptosis in Jurkat T lymphoblastic leukemia cells. Food Chem Toxicol 2012;50:2916-22.

26. Yi T, Yi Z, Cho SG, Luo J, Pandey MK, Agarwal BB, et al. Gambogic acid inhibits angiogenesis an dprostate tumor growth by supressing VEGFR2 signaling. Cancer Res 2008;68:1843-50.

27. Mohan S, Ibrahim S, Kamalidehghan B, Syam S, Sue K, Saad N, et al. Involvement of NF- $\kappa \mathrm{B}$ and $\mathrm{Bcl} 2$ / Bax signaling pathways in the apoptosis of MCF7 cells induced by a xanthone compound pyranocycloartobiloxanthone A. Phytomedicine 2012;19:1007-15.

28. Nakatani K, Nakahata N, Arakawa T, Yasuda H, Ohizumi Y. Inhibition of cyclooxygenase and prostaglandin E2 synthesis by $\alpha$-mangostin, a xanthone derivative in mangosteen, in C6 rat glioma cells. Biochem Pharmacol 2002;63:73-9.

29. Nakatani K, Yamakuni T, Kondo N, Arakawa T, Oosawa K, Shimura $\mathrm{S}$, et al. $\gamma$-mangostin inhibits inhibitor-B kinase activity and decreases lipopolysaccharide-induced cyclooxygenase-2 gene expression in C6 rat glioma cells. Mol Pharmacol 2004;66:667-74.

30. Navya A, Rayalu DJ, Devi PUM. Docking studies on xanthones of mangosteen as COX-2 inhibitors. Int J Appl Biol Pharm Technol 2011;513:263-8.

31. Das A, Parida P, Agarwal N, Shree J, Shankar B, Chakraborty D. (5 ' substituted pentyloxy) xanthone derivatives as PGHS-2 inhibitors. J Appl Pharm Sci 2013;3:S13-22.

32. Musfiroh IDA, Muhtadi A, Kartasasmita RE, Tjahjono DH. In silico study of asiatic acid interaction with inducible nitric oxide synthase (INOS) and cyclooxygenase-2 (COX-2). Int J Pharm Pharm Sci 2013;5:204-7.

33. Hafeez A, Saify ZS, Naz A, Yasmin F, Akhtar N. Molecular docking study on the interaction of riboflavin (Vitamin B 2) and cyanocobalamin (Vitamin B 12) coenzymes. J Comput Med 2013. http://dx.doi.org/10.1155/2013/312183. 
34. Korb 0, Stutzle T, Exner TE. Empirical scoring functions for advanced Protein-Ligand docking with PLANTS. J Chem Inf Model 2009;49:84-96.

35. Kartasasmita RE, Herowati R, Harmastuti N, Gusdinar T. Quercetin derivatives docking based on study of flavonoids interaction to cyclooxygenase-2docking turunan kuersetin berdasarkan studi interaksi flavonoid terhadap enzim. Indo J Chem 2009;9:297-302.

36. Huang S, Zou X. Efficient molecular docking of NMR structures: application to HIV-1 protease. Protein Sci 2007;16:43-51.

37. Prasojo SL, Agung F, Hartanto D, Yuniarti N. Docking of 1phenylsulfonamide-3-trifluoromethyl-5-parabromophenylpyrazole to cyclooxygenase-2 using plants. Indo J Chem 2010;10:348-51.

38. DeLano WL. Review: the case for open-source software in drug discovery. Drug Discov Today 2005;10:213-7.

39. Habeeb AG, Rao PNP, Knaus EE. Design and synthesis of celecoxib and rofecoxib analogues as selective cyclooxygenase2 (COX-2) inhibitors: replacement of sulfonamid and methylsulphonyl pharmacophores by and azido bioisostere. J Med Chem 2001;44:3039-42.

40. Kerr S, Gailer J. COX-2-selective NSAIDs: New wonder drugs? National Prescribing Service, New South Wale; 2010.

41. Zarghi A, Arfaei S. Selective COX-2 inhibitors: a review of their structure-activity relationships. Iran J Pharm Res 2011;10:655-83.

42. Meenambiga SS, Rajagopal K, Durga R. In silico docking studies on the components of inonotus sp., a medicinal mushroom against cyclooxygenase-2 enzyme. Asian J Pharm Clin Res 2015;8:142-5.
43. Kumar V, Gupta GK, Kaur K, Singh R. 4-Fluorophenylhydrazones as potential COX-2 inhibitors: a novel, efficient, one pot solid phase synthesis, docking study and pharmacological evaluation. Med Chem Res 2013;22:5890-900.

44. Zebardast T, Zarghi A, Daraie B, Hedayati M, Dadrass OG. Design and synthesis of 3-alkyl-2-aryl-1,3-thiazinan-4-one derivatives as selective cyclooxygenase (COX-2) inhibitors. Bioorg Med Chem Lett 2009;19:3162-5.

45. Dilber S, Dobric S, Juranic Z, Markovic B, Vladimirov S, Juranic I. Docking studies and anti-inflammatory activity. Molecules 2008;13:603-15.

46. Dhingra M, Deb P, Chadha R, Singh T, Karan M. Synthesis, evaluation, and molecular docking studies of cycloalkyl/and gastroprotective anti-inflammatory agents. Med Chem Res 2014:23:87-106.

47. Mello PD, Gadhwal MK, Joshi U, Shetgiri P. Modeling of COX-2 inhibitory activity of flavonoids. Int J Pharm Pharm Sci 2011;3:37-40.

48. Gautam R, Jachak SM, Kumar V, Mohan CG. Synthesis, biological evaluation and molecular docking studies of stellatin derivatives as cyclooxygenase (COX-1, COX-2) inhibitors and anti-inflammatory agents. Bioorg Med Chem Lett 2011;21:1612-6.

\section{How to cite this article}

- Isnatin Miladiyah, Jumina Jumina, Sofia Mubarika Haryana, Mustofa Mustofa. In silico molecular docking of xanthone derivatives as cyclooxygenase-2 inhibitor agents. Int J Pharm Pharm Sci 2017;9(3):98-104. 